\title{
Natural fortification of trout with dietary macroalgae and selenised-yeast increases the nutritional contribution in iodine and selenium
}

\author{
Ana Ramalho Ribeiro a,*, Amparo Gonçalves ${ }^{\text {b,c }}$, Narcisa Bandarra ${ }^{\text {b,c }}$, Maria Leonor Nunes ${ }^{\text {b,c }}$, \\ Maria Teresa Dinis ${ }^{a}$, Jorge Dias ${ }^{\mathrm{d}}$, Paulo Rema ${ }^{\mathrm{e}}$ \\ a CCMAR, Universidade do Algarve, Campus de Gambelas, 8005-139 Faro, Portugal \\ b IPMA, Rua Alfredo Magalhães Ramalho, 6, 1495-006 Lisboa, Portugal \\ c CIIMAR/CIMAR, Universidade do Porto, Rua do Bragas, 4050-123 Porto, Portugal \\ d SPAROS Lda, Área Empresarial de Marim, Lote C, 8700-221 Olhão, Portugal \\ e CECAV, UTAD Universidade de Trás-os-Montes e Alto Douro, Quinta de Prados, Apartado 1013, 5001-801 Vila Real, Portugal
}

\section{A R T I C L E I N F O}

\section{Article history:}

Received 31 July 2016

Received in revised form 14 October 2016

Accepted 16 October 2016

Available online $\mathrm{xxxx}$

\section{Keywords:}

Rainbow trout

Iodine

Selenium

Vitamin $\mathrm{D}_{3}$

Fortification

Nutritional contribution

\begin{abstract}
A B S T R A C T
Fish and seafood consumption are increasing worldwide and the contribution of aquaculture products to consumers' diets is significant. External feeding in aquaculture unlocks the possibility of tailoring fish products with health beneficial compounds. A study was undertaken to evaluate the feed fortification with an iodinerich macroalgae (Laminaria digitata) and selenised yeast, at its maximum permitted levels, on minerals and vitamins content in rainbow trout edible part. Dietary supplementation resulted in a six-fold increase for iodine and a 2.9-fold increase for selenium contents in trout fillets without altering sensorial traits. The fortified fish presented a nutritional contribution of $12.5 \%$ DRI for iodine and $78 \%$ DRI for selenium, but all produced fish could supply $80 \%$ DRI for vitamin $\mathrm{D}_{3}$. Overall, fish from this trial could be labelled as "high in selenium and high in vitamin $\mathrm{D}_{3}$ " under the EFSA definition for a functional food.
\end{abstract}

(c) 2016 Elsevier Ltd. All rights reserved.

\section{Introduction}

Fish and shellfish are generally associated with healthy dietary patterns and improved wellbeing. Seafood is a valuable source of multiple essential nutrients, since most species provide the recommended amounts of n-3 long-chain polyunsaturated fatty acids (n-3 LCPUFA), contributing also to cover the needs of other essential nutrients, such as vitamin D, iodine or selenium (European Food Safety Authority EFSA, 2014a). In recent years, the identification of functional bioactive nutrients from marine origin and their biological effects has been the object of important research efforts (Shahidi \& Ambigaipalan, 2015). High fish consumption, with high n-3 LCPUFA levels, namely eicosapentaenoic (EPA; 20:5n-3) and docosahexaenoic (DHA; 22:6n3 ) fatty acids, has been unequivocally associated to a protective role against a number of human diseases (FAO/WHO, 2011; Raatz, Silverstein, Jahns \& Picklo, 2013). Other essential nutrients such as selenium, iodine and vitamin $\mathrm{D}$, of which fish is considered the main dietary source have also been positively correlated with disease prevention and improved health status. Additionally, recent studies suggest that some health benefits, attributed to LCPUFA, may be potentiated in the

\footnotetext{
* Corresponding author at: Centro de Ciências do Mar do Algarve, Universidade do Algarve, Campus de Gambelas, 8005-139 Faro, Portugal.

E-mail address: anarribeiro@gmail.com (A. Ramalho Ribeiro).
}

presence of selenium (Berr et al., 2009) and iodine (Bath, Steer, Golding, Emmett \& Rayman, 2013). These outcomes reinforce the importance of eating fish for its holistic properties rather than the ingestion of pills or supplements. A food-based approach has also been recommended by nutritionists for achieving nutrient adequacy, preventing and treating diseases. Dietary guidelines recommend at least two fish portions per week with cardiovascular protective effects and up to four servings per week during pregnancy with better functional outcomes of neurodevelopment in children (EFSA, 2014a).

Worldwide seafood consumption is steadily expanding, with per capita records of $20 \mathrm{~kg}$ in 2014, and prospects are to continue rising in the next years (FAO, 2015). Provision of seafood from capture fisheries is declining though aquaculture is overcoming this supply issue and the actual contribution at world level already overtook that of wild fish for human consumption (FAO, 2015). However, the current trend in aquafeeds for replacing marine-derived ingredients (fish meal and fish oil) by vegetable protein and oil sources can interfere with the fish nutritional profile. For instance, vegetable ingredients are often characterized by low amounts of n-3 LCPUFAs. Although conditioned by the elemental soil content of cultivars, cereals, pulses and oilseeds are also poorer sources of iodine and selenium when compared to marine protein ingredients (Van Paemel, Dierick, Janssens, Fievez \& De Smet, 2010). Moreover, current levels of vitamins and minerals in fish feeds target an optimal fish growth and welfare, without regarding a 
potential enhancement of the beneficial effects to consumers' health. Within this scenario, a new perspective towards consumers' dietary needs must be considered when designing aquafeeds. Fillets traits have already been effectively changed by modulating fish feeds in terms of bioactive fatty acids (Kennedy, Bickerdike, Berge, Dick \& Tocher, 2007; Ramos et al., 2008; Rosa, Andrade, Bandarra \& Nunes, 2010), selenium (Lorentzen, Maage \& Julshamn, 1994; Schram, Schelvis-Smit, Van Der Heul \& Luten, 2010) and iodine (Julshamn, Maage, Waagbø, \& Lundebye, 2006; Ramalho Ribeiro et al., 2015). However, the efficacy of muscle fortification seems to be dependent on supplemental dose, feeding strategies and also important the supplement product form (inorganic vs. organic). Additionally, some of these studies also lack an overall assessment regarding the nutritional contribution of fish to human consumption.

A dietary fortification trial was performed with rainbow trout owed to its importance as a major freshwater species consumed in Europe. The macroalgae Laminaria digitata and selenium-enriched yeast were used as iodine and selenium sources and their effects on fish fortification were evaluated, either isolated or concomitantly. Afterwards, the nutritional contribution was estimated and sensorial traits of trout fillets were also assessed.

\section{Material and methods}

\subsection{Experimental diets}

Four experimental diets were formulated to be isonitrogenous ( $42.7 \%$ crude protein), isolipidic (23.3\% crude fat) and isoenergetic (23.5 $\mathrm{MJ} \cdot \mathrm{kg}^{-1}$ gross energy) (Table 1$)$. A control diet (CTRL), similar to a commercial trout feed was formulated to contain $1.9 \mathrm{mg}$ iodine $\cdot \mathrm{kg}^{-1}$ supplied as potassium iodide and $0.25 \mathrm{mg}$ selenium $\cdot \mathrm{kg}^{-1}$, supplied as sodium selenite through the mineral premix and the endogenous content of the various ingredients. Based on this control formulation, three other experimental diets were manufactured. The LAM diet targeted an iodine level of $20 \mathrm{mg} \cdot \mathrm{kg}^{-1}$, supplied as Laminaria digitata, an iodine-rich macroalgae; SE diet targeted a total selenium level of $0.5 \mathrm{mg} \cdot \mathrm{kg}^{-1}$, supplied partially as selenium enriched yeast and LAMSE diet with a simultaneous supplementation of $20 \mathrm{mg}$ iodine $\cdot \mathrm{kg}^{-1}$, as Laminaria digitata, and of $0.5 \mathrm{mg}$ selenium $\cdot \mathrm{kg}^{-1}$, supplied as selenised yeast. The levels of $20 \mathrm{mg}$ iodine $\cdot \mathrm{kg}^{-1}$ and $0.5 \mathrm{mg}$ selenium $\cdot \mathrm{kg}^{-1}$ were adopted since it is the currently authorized maximum content of total iodine and selenium in complete feeds for fish in the European market. Experimental extruded diets were manufactured at SPAROS Lda (Olhão, Portugal).

\subsection{Growth trial and sampling}

The trial was conducted at the Experimental Research Station of University of Trás-os-Montes e Alto Douro (UTAD, Portugal). Experiments were directed by trained scientists (following category C FELASA recommendations) and in compliance with the European (Directive 2010/63/ EU) and Portuguese (Decreto-Lei ${ }^{\circ}$. 113/2013, de 7 de Agosto) legislation on the protection of animals for scientific purposes. UTAD facilities and their staff are certified to house and conduct experiments with live animals ('group-1' license by the 'Direção Geral de Veterinária', Ministry of Agriculture, Rural Development and Fisheries of Portugal).

Eight homogenous groups of 48 rainbow trout each, with a mean initial body weight of $238 \mathrm{~g}$ were stocked in $350 \mathrm{~L}$ fiberglass tanks, supplied with flow-through freshwater (water-flow rate: $7 \mathrm{~L} \cdot \mathrm{min}^{-1}$, temperature: $15 \pm 1^{\circ} \mathrm{C}$ ) and exposed to natural photoperiod conditions (14 light/10 h dark). Each experimental treatment was tested in duplicate tanks over 91 days. Fish were hand-fed to apparent satiety, twice a day. Final samplings were done $48 \mathrm{~h}$ following the last meal and fish were slaughtered by immersion in ice-water slurry (4:1) until death. At the start ( 6 fish from the initial stock) and at the end of the trial, three fish from each tank were sampled for analysis of whole-body
Table 1

Ingredients and proximate composition of experimental diets.

\begin{tabular}{|c|c|c|c|c|}
\hline Ingredients, $\mathrm{g} \cdot \mathrm{kg}^{-1}$ & CTRL & LAM & SE & LAMSE \\
\hline Fishmeal LT 70a & 125.00 & 125.00 & 125.00 & 125.00 \\
\hline Fishmeal $60^{\mathrm{b}}$ & 50.00 & 50.00 & 50.00 & 50.00 \\
\hline Soy protein concentrate ${ }^{c}$ & 160.00 & 160.00 & 160.00 & 160.00 \\
\hline Wheat gluten $^{\mathrm{d}}$ & 100.00 & 100.00 & 100.00 & 100.00 \\
\hline Corn gluten ${ }^{\mathrm{e}}$ & 100.00 & 100.00 & 100.00 & 100.00 \\
\hline Soybean meal ${ }^{\mathrm{f}}$ & 50.00 & 50.00 & 50.00 & 50.00 \\
\hline Rice protein concentrate ${ }^{g}$ & 50.00 & 50.00 & 50.00 & 50.00 \\
\hline Wheat meal & 121.30 & 117.65 & 121.20 & 117.55 \\
\hline Fish oil ${ }^{\text {h }}$ & 195.00 & 195.00 & 195.00 & 195.00 \\
\hline $\begin{array}{l}\text { Vitamin \& mineral } \\
\text { premix }^{\mathrm{i}}\end{array}$ & 10.00 & 10.00 & 10.00 & 10.00 \\
\hline Soy lecithin & 2.00 & 2.00 & 2.00 & 2.00 \\
\hline Guar gum & 4.00 & 4.00 & 4.00 & 4.00 \\
\hline Zeolite & 10.00 & 10.00 & 10.00 & 10.00 \\
\hline Antioxidant & 2.00 & 2.00 & 2.00 & 2.00 \\
\hline Dicalcium phosphate & 11.40 & 11.40 & 11.40 & 11.40 \\
\hline Astaxanthin & 0.30 & 0.30 & 0.30 & 0.30 \\
\hline L-Lysine & 7.00 & 7.00 & 7.00 & 7.00 \\
\hline DL-Methionine & 2.00 & 2.00 & 2.00 & 2.00 \\
\hline Macroalgae (Laminaria) ${ }^{\mathrm{j}}$ & & 3.65 & & 3.65 \\
\hline Selenised yeast ${ }^{\mathrm{k}}$ & & & 0.10 & 0.10 \\
\hline Dry matter (DM), \% & $95.2 \pm 0.1$ & $95.7 \pm 0.1$ & $96.0 \pm 0.2$ & $95.8 \pm 0.0$ \\
\hline Crude protein, \%DM & $42.7 \pm 0.1$ & $42.6 \pm 0.4$ & $42.7 \pm 0.0$ & $42.8 \pm 0.1$ \\
\hline Crude fat, \% DM & $23.3 \pm 0.1$ & $23.4 \pm 0.2$ & $23.4 \pm 0.1$ & $23.4 \pm 0.1$ \\
\hline Ash, \% DM & $8.5 \pm 0.0$ & $8.8 \pm 0.1$ & $8.7 \pm 0.1$ & $8.8 \pm 0.1$ \\
\hline $\begin{array}{l}\text { Gross energy, } \mathrm{MJ} \cdot \mathrm{kg}^{-1} \\
\quad \text { DM }\end{array}$ & $23.5 \pm 0.1$ & $23.6 \pm 0.2$ & $23.5 \pm 0.1$ & $23.5 \pm 0.0$ \\
\hline Total phosphorus, \% DM & $\begin{array}{l}1.13 \\
\pm 0.02\end{array}$ & $1.21 \pm 0.03$ & $\begin{array}{l}1.14 \\
\pm 0.02\end{array}$ & $1.20 \pm 0.01$ \\
\hline Iodine, $\mathrm{mg} \cdot \mathrm{kg}^{-1} \mathrm{DM}$ & $\begin{array}{l}1.89 \\
\pm 0.11\end{array}$ & $\begin{array}{l}22.70 \\
\pm 1.49\end{array}$ & $\begin{array}{l}2.09 \\
\pm 0.06\end{array}$ & $\begin{array}{l}22.35 \\
\pm 3.13\end{array}$ \\
\hline Selenium, $\mathrm{mg} \cdot \mathrm{kg}^{-1} \mathrm{DM}$ & $\begin{array}{l}0.24 \\
\pm 0.02\end{array}$ & $0.26 \pm 0.02$ & $\begin{array}{l}0.53 \\
\pm 0.02\end{array}$ & $0.51 \pm 0.01$ \\
\hline
\end{tabular}

a Peruvian fishmeal LT: 71\% crude protein (CP), 11\% crude fat (CF), EXALMAR, Peru.

b Fair Average Quality (FAQ) fishmeal: 62\% CP, 12\%CF, COFACO, Portugal.

c Soycomil P: $65 \%$ CP, 0.8\% CF, ADM, The Netherlands.

d VITEN: $85.7 \% \mathrm{CP}, 1.3 \% \mathrm{CF}$, ROQUETTE, France.

e Corn gluten meal: $61 \% \mathrm{CP}, 6 \% \mathrm{CF}, \mathrm{COPAM}$, Portugal.

f Solvent extracted dehulled soybean meal: $47 \%$ CP, 2.6\% CF, SORGAL SA, Portugal.

g Rice 50: 48.3\%CP, 6.5\% CF, SEAH International, France.

$\mathrm{h}$ COPPENS International, The Netherlands.

Premix for marine fish, PREMIX Lda, Portugal. Vitamins (IU or $\mathrm{mg} \cdot \mathrm{kg}^{-1}$ diet): DL-alpha tocopherol acetate, $100 \mathrm{mg}$; sodium menadione bisulphate, $25 \mathrm{mg}$; retinyl acetate, 20,000 IU; DL-cholecalciferol, $2000 \mathrm{IU}$; thiamin, $30 \mathrm{mg}$; riboflavin, $30 \mathrm{mg}$; pyridoxine, $20 \mathrm{mg}$; cyanocobalamin, $0.1 \mathrm{mg}$; nicotinic acid, $200 \mathrm{mg}$; folic acid, $15 \mathrm{mg}$; ascorbic acid $1000 \mathrm{mg}$; inositol, $500 \mathrm{mg}$; biotin, $3 \mathrm{mg}$; calcium pantothenate, $100 \mathrm{mg}$; choline chloride, $1000 \mathrm{mg}$, betaine, $500 \mathrm{mg}$. Minerals ( $\mathrm{g}$ or $\mathrm{mg} \cdot \mathrm{kg}^{-1}$ diet): cobalt carbonate, $0.65 \mathrm{mg}$; copper sulphate, $9 \mathrm{mg}$; ferric sulphate, $6 \mathrm{mg}$; potassium iodide, $0.5 \mathrm{mg}$; manganese oxide, $9.6 \mathrm{mg}$; sodium selenite, $0.01 \mathrm{mg}$; zinc sulphate, $7.5 \mathrm{mg}$; sodium chloride, $400 \mathrm{mg}$; calcium carbonate, $1.86 \mathrm{~g}$; excipient wheat middlings.

j Dry Laminaria digitata: 5.4\% CP, 0.5\% CF, $3700 \mathrm{mg}$ iodine $\cdot \mathrm{kg}^{-1}$, Agrimer, France.

k ALKOSEL R397: $2200 \mathrm{mg}$ selenium $\cdot \mathrm{kg}^{-1}$, Lallemand, France.

composition. Moreover, trout skinless fillets were collected at the start $(\mathrm{n}=3)$ and at the end of trial $(\mathrm{n}=2$ pools of 3 fish each), stored at $-80^{\circ} \mathrm{C}$ for analysis of minerals and vitamins content and fatty acid composition. For sensory analysis, ten fish from each treatment were weighed, scaled, filleted and kept at $4{ }^{\circ} \mathrm{C}$ until sensory assessment.

\subsection{Analytical methods}

Proximate composition analysis of the diets and whole fish was made by the following procedures: dry matter by drying at $105^{\circ} \mathrm{C}$ for $24 \mathrm{~h}$; ash by combustion at $550{ }^{\circ} \mathrm{C}$ for $12 \mathrm{~h}$; crude protein $(\mathrm{N} \times 6.25)$ through the release of nitrogen by a combustion technique followed by thermal conductivity detection (LECO FP528, Leco Instruments, USA); crude fat after dichloromethane (CID: 6344) extraction by the Soxhlet method; total phosphorus in the feeds was quantified according to the ISO/DIS 6491 method using the vanado-molybdate reagent; and gross energy in an adiabatic bomb calorimeter (model C2000, IKA- 
Werke GmbH \& Co. KG, Staufen, Germany). Minerals (Fe, Zn, Mg, K, I and Se) content in feeds and fillets was determined at an external certified laboratory (Silliker, Mérieux Nutrisciences, Portugal) by microwave digestion with nitric acid and hydrogen peroxide (CID: 784), followed by inductively coupled plasma mass spectrometry (ICP-MS) detection. Digested sample solutions were analysed for I, Se, Fe, $\mathrm{Zn}, \mathrm{K}$ and $\mathrm{Mg}$ using certified external calibration standards (Inorganic Ventures Europe S.L., Spain). Standards were prepared by systematically diluting $1000 \mu \mathrm{g} \cdot \mathrm{mL}^{-1}$ stock solutions of the respective elements and the calibration curves of five concentration points showed correlation coefficients $(R)$ between 0.995 and 1 . Reagent blanks $(n=6)$ were prepared in identical conditions. Spiking was performed, for each element, in two trout fillet samples as a method validation tool. Recovery values were in the range 93.7-106.1\%, which felt within the acceptance level of the certified laboratory. Limit of detection (LOD) and limit of quantification (LOQ) were calculated by the formulas LOD $=3 \sigma / \mathrm{b}$ and $\mathrm{LOQ}=10 \sigma / \mathrm{b}$, where $\sigma=$ standard deviation of the blank and $\mathrm{b}=$ slope of the calibration curve. The LOD $\left(\mathrm{mg} \cdot \mathrm{kg}^{-1}\right)$ for the various elements were: I (0.0004), Se (0.0013), Fe (0.0632), Zn (0.0034), K (0.0022) and $\mathrm{Mg}(0.0844)$. The LOQ $\left(\mathrm{mg} \cdot \mathrm{kg}^{-1}\right)$ for the various elements were: I (0.0011), Se (0.0227), Fe (0.1172), Zn (0.0086), K (0.0054) and $\mathrm{Mg}$ (0.2212). The same external laboratory determined also Vitamin $\mathrm{D}_{3}$ (cholecalciferol) by reversed phase HPLC with UV detection, according to the AOAC method 2002.05 and vitamin A (all-E-retinol, 13-Z-retinol) by HPLC according to EN 12823-1:2014 method. Total lipids in the fillets were extracted according to the method of Folch, Lees and Stanley (1957). The fatty acid composition of fillets was determined by gaschromatographic analysis of methyl esters, according to the procedure of Lepage and Roy (1986), modified by Cohen, Vonshak and Richmond (1988) and described in further detail by Costa et al. (2013). Data in $\mathrm{mg} / 100 \mathrm{~g}$ of edible part were calculated using the peak area ratio (\% of total fatty acids) and the lipid conversion factors set by Weihrauch, Posati, Anderson and Exler (1977). Based on the fatty acid profile of trout fillets, the atherogenic (1) and thrombogenic (2) index (AI and $\mathrm{TI}$, respectively) were calculated accordingly to Ulbricht and Southgate (1991) for evaluation of the predisposition for incidence of coronary heart disease.

$\mathrm{AI}=\frac{\mathrm{C} 12: 0+(4 \times \mathrm{C} 14: 0)+\mathrm{C} 16: 0}{\text { Total MUFA }+ \text { Total } \mathrm{n}-3+\text { Total } \mathrm{n}-6}$

$\mathrm{C} 14: 0+\mathrm{C} 16: 0+\mathrm{C} 18: 0$

$(0.5 \times$ Total MUFA $)+(0.5 \times$ Total $n-6)+(3 \times$ Total $n-3)+$ ratio $n-3 / n-6$

(2)

\subsection{Nutritional contribution}

The nutritional contribution (NC) of trout fillets was calculated as the percentage of the Daily Recommended Intake (DRI)/Dietary reference values (DRVs) for selected minerals and vitamins and also of the Daily Adequate Intake (DAI) for combined EPA and DHA. When distinct recommendations exist for males and females, calculations were adapted accordingly and the following formula (3) was used:

$\mathrm{NC}(\%)=100 \times \frac{\mathrm{C} \times \mathrm{M}}{\mathrm{DRI} / \mathrm{DRV} \text { or DAI }}$

where: C: mean concentration of nutrient in $\mathrm{g} \cdot \mathrm{kg}^{-1}, \mathrm{mg} \cdot \mathrm{kg}^{-1}$ or $\mu \mathrm{g} \cdot \mathrm{kg}^{-1}$. M: meal fillet portion consumed is $0.160 \mathrm{~kg}$ (Costa et al., 2013). DRV established as Adequate Intake (AI) for iodine is $0.150 \mathrm{mg} \cdot \mathrm{d}^{-1}$ for adults (EFSA, 2014b). DRV established as Adequate Intake (AI) for selenium is $0.070 \mathrm{mg} \cdot \mathrm{d}^{-1}$ for adults (EFSA, 2014c). DRI established as Recommended Dietary Allowance for iron is $8.0 \mathrm{mg} \cdot \mathrm{d}^{-1}$ for males and $18 \mathrm{mg} \cdot \mathrm{d}^{-1}$ for females (Institute of Medicine IOM, 2001). DRV established as Population Reference Intakes (PRIs) for zinc are 7.5 to $12.7 \mathrm{mg} \cdot \mathrm{d}^{-1}$ for women (mean value $=10.1 \mathrm{mg} \cdot \mathrm{d}^{-1}$ ) and 9.4 to $16.3 \mathrm{mg} \cdot \mathrm{d}^{-1}$ for men (mean value $\left.=12.9 \mathrm{mg} \cdot \mathrm{d}^{-1}\right)(\mathrm{EFSA}$, 2014d). DRI established as Adequate Intake (AI) for potassium is $4.7 \mathrm{~g} \cdot \mathrm{d}^{-1}$ for adolescents and adults (IOM, 2005). DRV established as Adequate Intake $(\mathrm{AI})$ for magnesium is $350 \mathrm{mg} \cdot \mathrm{d}^{-1}$ for adult males and $300 \mathrm{mg} \cdot \mathrm{d}^{-1}$ for adult females (EFSA, 2015a). DRI established as Recommended Dietary Allowance for Vitamin D is $15.0 \mu \mathrm{g} \cdot \mathrm{d}^{-1}$ for young and adults (IOM, 2011). DRV established as Population Reference Intakes (PRIs) for Vitamin A is $750 \mu \mathrm{g}$ retinol $\cdot \mathrm{d}^{-1}$ for men and $650 \mu \mathrm{g}$ retinol $\cdot \mathrm{d}^{-1}$ for women (EFSA, 2015b). DAI for EPA + DHA is $500 \mathrm{mg} \cdot \mathrm{d}^{-1}$ for primary prevention of cardiovascular disease in adults (International Society for the Study of Fatty Acids and Lipids ISSFAL, 2004), corresponding to a weekly intake of $3.5 \mathrm{~g}$ of EPA + DHA.

\subsection{Sensorial evaluation}

Sensory evaluation was carried out in an acclimatized room equipped with individual booths. To reduce the variability within the fillets, the parts close to the head and the tail were rejected. Each skinon fillet was individually wrapped with aluminium foil to avoid odour losses and cooked for $6 \mathrm{~min}$ at $100{ }^{\circ} \mathrm{C}$ in a saturated steam oven (Rational Combi-Master CM6 Cross KuchentechnikCmbH, Landsberg, Germany). A multisample difference test was conducted (Meilgaard, Civille \& Carr, 1999) using a sensory panel composed by ten trained panellists. Cooked fillets were presented to the panellists sequentially in coded white dishes under normal white lighting. Each panellist received the four samples in a balanced random order and rated the intensity of sensory attributes on a 9-point scale ranging from absent $(0)$ to very intense ( 8 points). The attributes selected were the odour, taste and texture (firmness and succulence).

\subsection{Statistical analysis}

Growth performance and fillet nutrient composition are expressed as means of two replicates \pm standard deviation. Data (including sensory data) were subjected to a one-way analysis of variance. Parameters expressed as percentages were subjected to arcsin square root transformation. Following ANOVA, means were compared by the Tukey HSD multiple comparison test. Statistical significance was tested at 0.05 probability level. All statistical tests were performed using the SPSS software (v22, IBM, USA).

\section{Results}

At the end of the trial, fish reached a final body weight ranging from 335 to $350 \mathrm{~g}$ and both Laminaria and selenised yeast supplemented feeds led to a significant increase $(P=0.020)$ of final body weight (Table 2). Feed intake was not affected by the various dietary treatments $(P=0.168)$. FCR was highest in fish the CTRL diet and significantly reduced in those fed diets supplemented with Laminaria and selenised yeast $(\mathrm{P}=0.004)$. Moreover, fish fed the diets supplemented with selenised yeast (SE and LAMSE) presented lower FCR than those fed diet LAM. The whole-body composition of fish, in terms of moisture, protein, fat and ash, was not affected by the dietary treatments $(\mathrm{P}>0.05)$ (Table 2).

Dietary fortification strategies led to a significant increase $(\mathrm{P}<0.001)$ of iodine and selenium content in rainbow trout fillets (Table 3). Trout fed Laminaria digitata supplemented diets showed a significant increase $(\mathrm{P}<0.001)$ of their fillet iodine content $\left(0.12 \mathrm{mg} \cdot \mathrm{kg}^{-1}\right)$, representing a six-fold increase over the iodine levels found in the CTRL treatment $\left(0.02 \mathrm{mg} \cdot \mathrm{kg}^{-1}\right)$. Similarly, trout fed with selenium-enriched yeast resulted in a significant 2.9-fold increase in muscle selenium content $\left(0.43 \mathrm{mg} \cdot \mathrm{kg}^{-1}\right)$, when compared to the selenium level in the CTRL treatment $\left(0.15 \mathrm{mg} \cdot \mathrm{kg}^{-1}\right)$. The concomitant supplementation of Laminaria macroalgae and selenium-enriched yeast (LAMSE diet) significantly increased both selenium and iodine 
Table 2

Growth performance and whole-body composition of fish.

\begin{tabular}{llllll}
\hline & CTRL & LAM & SE & LAMSE & P-value \\
\hline $\mathrm{IBW}^{1}, \mathrm{~g}$ & $237.5 \pm 1.2$ & $238.1 \pm 1.5$ & $239.6 \pm 0.6$ & $237.3 \pm 2.7$ & \\
$\mathrm{FBW}^{2}, \mathrm{~g}$ & 334.9 & 343.4 & 349.0 & 349.6 & 0.020 \\
& $\pm 0.2^{\mathrm{a}}$ & $\pm 0.8^{\mathrm{b}}$ & $\pm 4.1^{\mathrm{b}}$ & $\pm 3.9^{\mathrm{b}}$ & \\
$\mathrm{FI}^{3}$ & $0.45 \pm 0.01$ & $0.44 \pm 0.00$ & $0.42 \pm 0.01$ & $0.44 \pm 0.01$ & 0.168 \\
$\mathrm{SGR}^{4}, \% \cdot \mathrm{d}^{-1}$ & $0.38 \pm 0.00$ & $0.40 \pm 0.00$ & $0.41 \pm 0.02$ & $0.43 \pm 0.00$ & 0.062 \\
$\mathrm{FCR}^{5}$ & 1.20 & 1.12 & $1.03 \pm 0.02^{\mathrm{c}}$ & $1.04 \pm 0.02^{\mathrm{c}}$ & 0.004 \\
& $\pm 0.02^{\mathrm{a}}$ & $\pm 0.01^{\mathrm{b}}$ & & & \\
& & & & \\
Whole-body composition & & & & \\
Moisture, \% & $70.5 \pm 0.2$ & $70.9 \pm 0.1$ & $70.6 \pm 0.3$ & $70.5 \pm 0.1$ & 0.172 \\
Protein, \% & $16.7 \pm 0.1$ & $16.8 \pm 0.1$ & $16.9 \pm 0.2$ & $17.1 \pm 0.1$ & 0.172 \\
Fat, \% & $9.6 \pm 0.2$ & $9.4 \pm 0.0$ & $9.6 \pm 0.1$ & $9.7 \pm 0.2$ & 0.400 \\
Ash, \% & $2.9 \pm 0.0$ & $2.9 \pm 0.1$ & $2.7 \pm 0.1$ & $2.8 \pm 0.1$ & 0.271
\end{tabular}

Values are means \pm standard deviation $(n=2)$. Absence of superscript letters within a row represents no significant differences between treatments $(\mathrm{P}>0.05)$.

1 Initial mean body weight.

2 Final mean body weight.

3 Feed intake: crude feed intake/(IBW + FBW) / 2 / 91 days

4 Specific growth rate: (Ln FBW - Ln IBW) $\times 100 / 91$ days.

5 Feed conversion ratio: dry feed intake/wet weight gain.

* Initial fish: moisture 74.7\%; Protein, 14.1\%; fat 8.2\%; ash $2.7 \%$.

levels in trout muscle, to similar levels as those found with individual supplementation strategies. The dietary inclusion of Laminaria macroalgae and selenium-enriched yeast had no effect $(P>0.05)$ on the fillet content of other minerals (iron, zinc, potassium and magnesium) and vitamins $\mathrm{A}$ and $\mathrm{D}_{3}$.

The nutritional contribution (NC) of trout fillets to cover the DRV of selected minerals and vitamins $\mathrm{A}$ and $\mathrm{D}_{3}$ in adults female and male is presented in Table 3 . The consumption of a $160 \mathrm{~g}$ portion of a CTRL trout fillet represented $2.5 \%$ and $33.8 \%$ of the DRV for iodine and selenium, respectively. Fillets of trout fed the iodine-rich macroalgae (LAM

\section{Table 3}

Vitamins and minerals content in rainbow trout fillets fed the various experimental diets and nutritional contribution as \% of Daily Reference Values (DRVs).

\begin{tabular}{|c|c|c|c|c|}
\hline & CTRL & LAM & SE & LAMSE \\
\hline Iodine, $\mathrm{mg} \cdot \mathrm{kg}^{-1}$ & $\begin{array}{l}0.02 \\
\pm 0.01^{\mathrm{a}}\end{array}$ & $0.12 \pm 0.01^{\mathrm{b}}$ & $0.02 \pm 0.00^{\mathrm{a}}$ & $0.12 \pm 0.00^{\mathrm{b}}$ \\
\hline Selenium, $\mathrm{mg} \cdot \mathrm{kg}^{-1}$ & $\begin{array}{l}0.15 \\
\pm 0.01^{\mathrm{a}}\end{array}$ & $0.14 \pm 0.01^{\mathrm{a}}$ & $0.43 \pm 0.01^{b}$ & $0.43 \pm 0.02^{\mathrm{b}}$ \\
\hline Iron, $\mathrm{mg} \cdot \mathrm{kg}^{-1}$ & $4.0 \pm 0.1$ & $4.0 \pm 0.3$ & $4.1 \pm 0.0$ & $4.1 \pm 0.2$ \\
\hline Zinc, $\mathrm{mg} \cdot \mathrm{kg}^{-1}$ & $3.3 \pm 0.1$ & $3.3 \pm 0.1$ & $3.3 \pm 0.0$ & $3.3 \pm 0.1$ \\
\hline Potassium, $\mathrm{g} \cdot \mathrm{kg}^{-1}$ & $4.9 \pm 0.0$ & $4.9 \pm 0.2$ & $4.8 \pm 0.1$ & $4.8 \pm 0.1$ \\
\hline $\begin{array}{l}\text { Magnesium, } \\
\mathrm{mg} \cdot \mathrm{kg}^{-1}\end{array}$ & $298.5 \pm 6.4$ & $\begin{array}{l}298.5 \\
\pm 14.8\end{array}$ & $\begin{array}{l}313.5 \\
\pm 16.3\end{array}$ & $\begin{array}{l}288.5 \\
\pm 13.4\end{array}$ \\
\hline Vitamin $D_{3}, \mu \mathrm{g} \cdot \mathrm{kg}^{-1}$ & $122.8 \pm 5.1$ & $119.8 \pm 7.2$ & $121.5 \pm 1.1$ & $118.7 \pm 4.9$ \\
\hline Vitamin $\mathrm{A}, \mu \mathrm{g} \cdot \mathrm{kg}^{-1}$ & $139.0 \pm 5.7$ & $142.0 \pm 2.8$ & $137.5 \pm 2.1$ & $140.5 \pm 3.5$ \\
\hline
\end{tabular}

Nutritional contribution

\begin{tabular}{|c|c|c|c|c|c|c|c|c|}
\hline$\% \mathrm{DRV}^{1,2}$ & Female & Male & Female & Male & Female & Male & Female & Male \\
\hline Iodine & 2.5 & & 12.5 & & 2.1 & & 12.4 & \\
\hline Selenium & 33.8 & & 31.8 & & 98.3 & & 97.8 & \\
\hline Potassium & 16.5 & & 16.7 & & 16.3 & & 16.2 & \\
\hline Iron & 3.6 & 8.0 & 3.6 & 8.0 & 3.6 & 8.2 & 3.6 & 8.1 \\
\hline Zinc & 5.1 & 4.0 & 5.2 & 4.1 & 5.2 & 4.1 & 5.1 & 4.0 \\
\hline Magnesium & 15.9 & 13.6 & 15.9 & 13.6 & 16.7 & 14.3 & 15.4 & 13.2 \\
\hline Vitamin $\mathrm{D}_{3}$ & 131.0 & & 127.8 & & 129.6 & & 126.6 & \\
\hline Vitamin A & 3.4 & 3.0 & 3.5 & 3.0 & 3.4 & 2.9 & 3.5 & 3.0 \\
\hline
\end{tabular}

Values are means \pm standard deviation $(n=2)$. Each replicate sample was a pool of three fillets.

Different superscripts within rows represent significant differences between treatments $(\mathrm{P}<0.05)$.

1 For definition of DRV calculations refer to Section 2.4.

2 DRV calculations took into account gender differences on recommendations. and LAMSE) covered $12.5 \%$ of iodine DRV, while those resulting from trout fed with selenised yeast accounted for $98 \%$ of selenium DRV. Although not affected by dietary treatments, vitamin $D_{3}$ content in trout fillets was high (119-123 $\left.\mu \mathrm{g} \cdot \mathrm{kg}^{-1}\right)$, and a $160 \mathrm{~g}$ meal covered $127-$ $131 \%$ of DRV. The nutritional contribution of all other nutrients ( Fe, $\mathrm{Zn}, \mathrm{K}, \mathrm{Mg}$, vitamin A) was not affected by dietary treatments.

The summarised fatty acid contents of trout fillets are presented in Table 4. Dietary incorporation of iodine-rich macroalgae and selenised yeast did not affect $(\mathrm{P}>0.05)$ the fillet profile in saturated (SFA), monounsaturated (MUFA) and polyunsaturated (PUFA) fatty acids. Consequently, total levels of n-3 and n- 6 fatty acids, its ratio and both thrombogenic $(\mathrm{TI})$ and atherogenic $(\mathrm{AI})$ indexes were also not affected by dietary treatments $(\mathrm{P}>0.05)$. The consumption of a $160 \mathrm{~g}$ portion of trout fillet, twice a week, represented $85-91 \%$ of the Weekly Adequate Intake (WAI) of combined EPA and DHA for the primary prevention of cardiovascular disease in adults.

Organoleptic properties of steamed cooked trout fillets were not affected by the dietary inclusion of Laminaria and selenised yeast $(P>0.05)$ (Fig. 1). Sensory panel rated typical odour as slight to moderate (evenly rated between treatments) and typical taste as moderate (with higher tendency in both Laminaria groups) to intense (with higher tendency in CTRL and SE groups). Additionally non-typical odour and non-typical taste were mainly classified as absent. Concerning texture-related criteria, succulence was scored as slight to moderate and firmness as moderate to intense.

Table 4

Summarised fatty acids content of fillets.

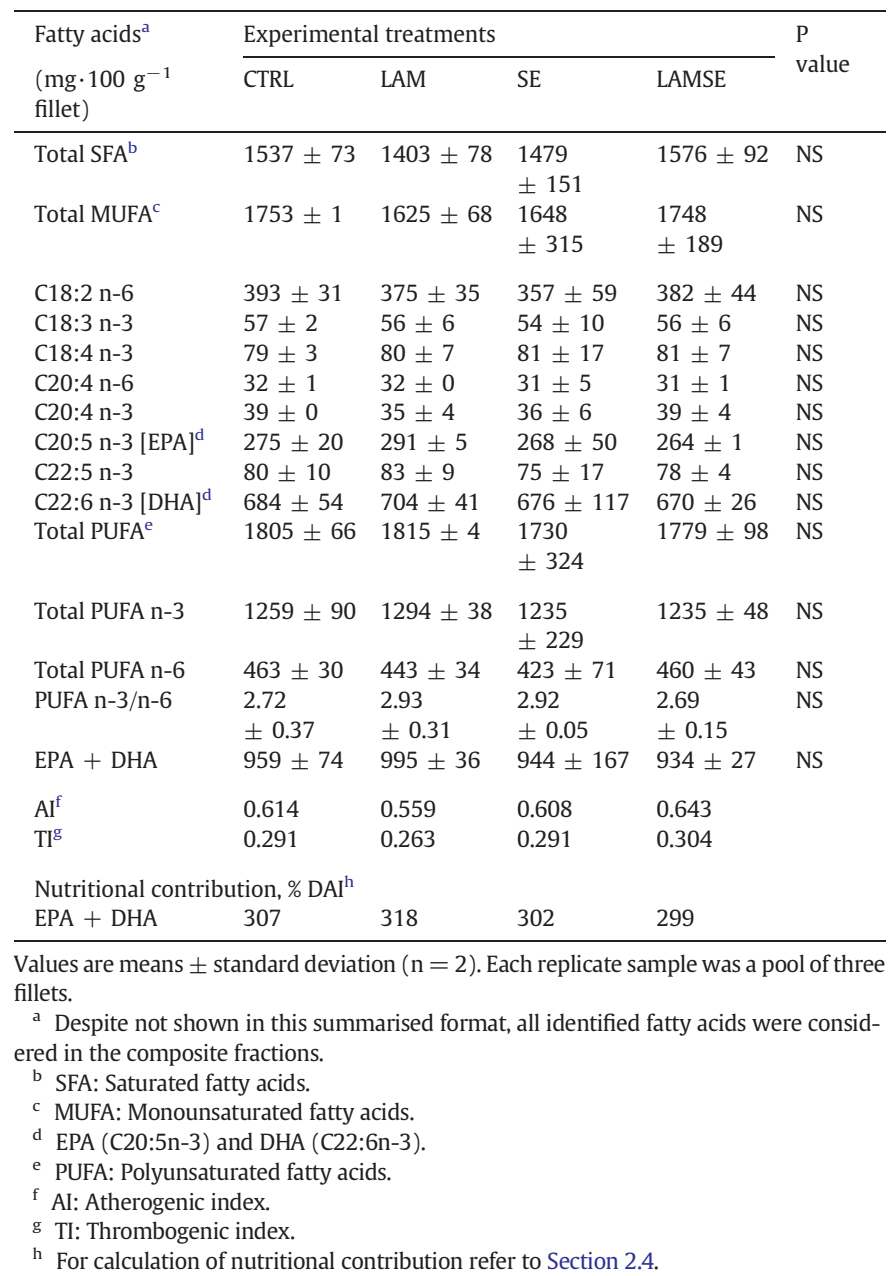




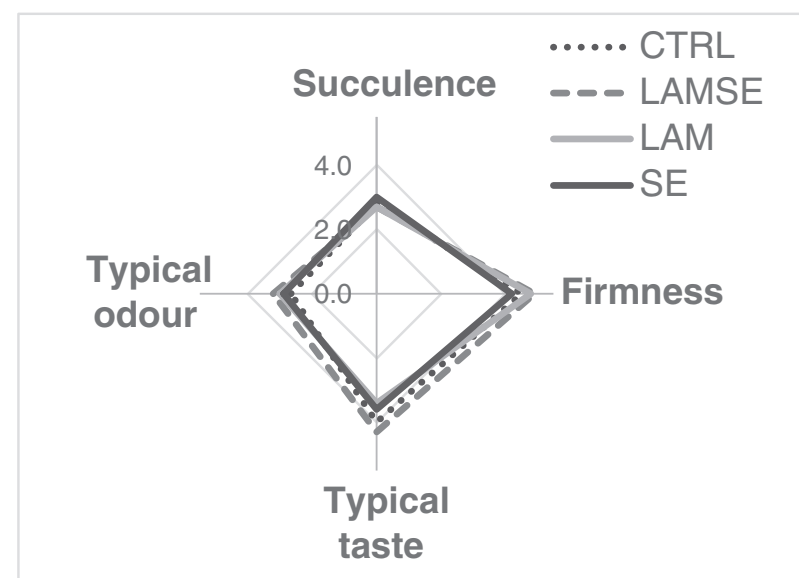

Fig. 1. Sensory analysis of steam-cooked trout fillets supplemented with macroalgae and selenised-yeast.

\section{Discussion}

Fish are a rich source of vitamin D, iodine, selenium and n-3 LCPUFA Nevertheless, their contents in seafood are extremely variable, not only among species but also between individuals of the same species (EFSA, 2014a). Although subjected to high variability, wild fish generally present higher iodine and selenium levels than farmed counterparts (Julshamn, Dahl \& Eckhoff, 2001; Maage, Julshamn \& Ulgenes, 1991). The current trend for replacing marine-derived ingredients by plant feedstuffs in fish diets may accentuate such differences and consequently change consumer expected intakes of health valuable nutrients. Moreover, it is known that fish feeds do not make full use of the maximum approved levels for iodine and selenium (EFSA, 2005). Therefore, dietary supplementation strategies can be used as tools to enhance the iodine and selenium content in fish fillets, in order to convey benefits beyond fulfilling the basic nutritional needs of the animal, namely in terms of its nutritional value to consumers.

Selenium levels in human populations are generally influenced by geographical region, due to soil content of selenium, seasonal changes, protein content and food processing (Navarro-Alarcon \& CabreraVique, 2008). A recent systematic data review indicate that Se intake and status is suboptimal in most European and Middle Eastern countries (Stoffaneller \& Morse, 2015). Potential approaches for enhancing human Se status comprise selenium soil fertilization; animal feed and food fortification; and intake of single supplements. In our study, an increase of current feed selenium level $\left(0.25 \mathrm{mg}\right.$ selenium $\left.\cdot \mathrm{kg}^{-1}\right)$ to maximum approved levels in the European market $\left(0.5 \mathrm{mg}\right.$ selenium $\left.\cdot \mathrm{kg}^{-1}\right)$ with a selenised-yeast led to a 2.9-fold increase for selenium contents in trout fillets. Although variable in the magnitude of selenium deposition, previous studies have also reported the successful Se fortification of fish fillets (Hunt et al., 2011; Küçükbay et al., 2009; Pacitti et al., 2015; Rodríguez \& Rojas, 2014). The utilization of organic Se sources, as selenised-yeast, is also advantageous, since organic bound selenium was found to be a higher bioavailable form of Se when compared to inorganic sources in rainbow trout fortification studies (Küçükbay et al., 2009; Rider et al., 2009). The daily nutritional contribution of a $160 \mathrm{~g}$ fillet portion was raised from $34 \%$ to $98 \%$ in the case of selenium fortified trout, considering a daily adequate intake for Se of $70 \mu \mathrm{g}$, as recently set by EFSA. Concerning the beneficial effects for human health, high selenium bioavailability was reported from fish and shellfish food items (Moreda-Piñeiro, Moreda-Piñeiro \& Bermejo-Barrera, 2015). One main achievement of our study was to establish the dietary use of selenised-yeast as an effective and natural strategy to fortify rainbow fillets in selenium.
Iodine deficiency is the world's greatest single cause of preventable brain damage, and this fact is the primary motivation behind the current worldwide drive to eliminate iodine deficiency (WHO, 2007). Deficiency is largely the result of inadequate iodine intake rather than poor absorption. The primary strategy for iodine supplementation relies on salt iodization. However, with the implementation of salt intake reduction programmes makes this strategy less effective and alternatives are required. In our study, trout fed diets supplemented with Laminaria digitata, showed a significant increase of their fillet iodine content, representing a six-fold increase over the iodine levels found in the regular fed trout. Dietary macroalgae have been successfully used to achieve higher iodine contents in rainbow trout (Valente et al., 2015), chars (Schmid et al., 2003) and gilthead seabream (Ramalho Ribeiro et al., 2015). Several of these studies report higher iodine fillet contents than the ones observed in the present trial. This variation is probably due to the different macroalgae used, dietary iodine levels tested and fish species considered. As described for other minerals, iodide $(\mathrm{I}-$ ) the predominant iodine species in macroalgae is reported to have a higher bioavailability compared to other inorganic compounds improving digestibility, absorption and retention in fish (Doucha, Lívanský, Kotrbáček \& Zachleder, 2009; Cotter, McLean \& Craig, 2009; Kouba, Velîšek, Stará, Masojídek \& Kozák, 2014). Trout subjected to our iodine fortification strategy, implemented within the maximum allowed levels $\left(20 \mathrm{mg} \cdot \mathrm{kg}^{-1}\right.$ ) in fish feeds, covered $12.5 \%$ of the daily adequate intake for adults, with a $160 \mathrm{~g}$ portion, considering a daily adequate intake for iodine of $150 \mu \mathrm{g}$. Literature data on the bioavailability of iodine from fish is limited. Nevertheless, good evidence exist that iodine accumulates in fish muscle in an inorganic and therefore a complete absorption after ingestion by humans is assumed (Hurrell, 1997). A work performed by Schmid et al. (2003) reported high bioavailability of iodine from $L$. digitata enriched chars in a trial with 14 volunteers, although potential cooking losses were not assessed stalling an accurate absorption measurement.

In most European countries, there seems to be a shortfall in achieving current vitamin D recommendations, particularly in older institutionalised adults and in some ethnic groups (Cashman, Fitzgerald, Kiely \& Seamans, 2011). Vitamin D status is highly dependent on several factors like diet, sunlight exposure and lifestyle. Fish are among the richest sources of vitamin $\mathrm{D}$, available as the $\mathrm{D}_{3}$ chemical form (Schmid \& Walther, 2013). Moreover, vitamin $D_{3}$ shows a higher efficacy to raise serum 25-hydroxycholecalciferol (25(OH)D) concentrations than vitamin $\mathrm{D}_{2}$ (Cashman et al., 2011). Despite not being the target of our fortification strategy, trout fillets fed the various experimental diets showed high vitamin $\mathrm{D}_{3}$ levels $\left(119-123 \mu \mathrm{g} \cdot \mathrm{kg}^{-1}\right)$.

In our study the main source of dietary lipids was marine fish oil and it remained unchanged among the various diets. Also, Laminaria and selenised yeast had no interference on muscle fatty acids profile. Therefore, the combined content of EPA and DHA $\left(0.96 \pm 0.08 \mathrm{~g} \cdot 100 \mathrm{~g}^{-1}\right.$ fresh fillet) and PUFA n-3/n-6 ratio (2.82 \pm 0.22$)$ in raw fillets was relatively constant among the various treatments. The consumption of a $160 \mathrm{~g}$ portion of trout fillets, twice a week, represented, on average, $88 \%$ of EPA and DHA combined Adequate Intake, as recommended for primary prevention of cardiovascular disease in adults (ISSFAL, 2004). Similarly, the fillet content of all other measured minerals (Fe, $\mathrm{Zn}, \mathrm{K}$, and $\mathrm{Mg}$ ) and vitamin A remained unaffected by the dietary supplementation strategies. The nutritional contribution of trout fillets evaluated according to the established recommended values for adults, and if applicable for men and women distinctively, shows that a portion of $160 \mathrm{~g}$ of fillet of any test group contributed to the daily adequate intake for potassium (16\%), magnesium (14\% men; $16 \%$ women), iron ( $8 \%$ men; $4 \%$ women), zinc ( $4 \%$ men; $5 \%$ women) and vitamin A (3\%). Most dietary guidelines convey the message that health benefits associated to a given nutrient are generally stronger when derived from a whole food matrix, as part of a synergistic dietary pattern, rather than its supply as a single supplement. Under this scenario, tailoring farmed fish with health beneficial compounds is becoming particularly important owed 
to the role of seafood as part of a healthy food pattern (EFSA, 2014a). Also of importance is the fact that the fortified trout fillets could be promoted in the functional foods market. According to EC 1924/2006 regulation, in the European market, a food item can be labelled as "source of selenium" if it supplies $15 \%$ of the DRV in $100 \mathrm{~g}$ of product and "high in selenium" in case of containing at least twice this value (30\% of selenium DRV). Under this definition, the selenium supplemented fillets produced in our trial could be labelled with a nutrition claim like "high source of selenium" since it supplies $43 \mu \mathrm{g}$ selenium $\cdot 100 \mathrm{~g}^{-1}$ (61\% of DRV). Similarly, all produced fillets could be labelled as "high source of vitamin $\mathrm{D}_{3}$ ", since on average they provide $80.5 \%$ of RDI in $100 \mathrm{~g}$ of food item. Therefore these food items could be considered as functional foods (EFSA, 2009; EFSA, 2015c).

In spite of actual consumer request for healthy food, there is also awareness about the natural sensory properties of food items (Verbeke, 2005). Thus, a nutritional fortification of food should avoid any negative effects on the sensory traits. In the current trial, dietary supplementation with selenised yeast and/or iodine-rich macroalgae did not alter organoleptic characteristics of steamed cooked trout fillets. Typical taste and typical odour, usually determinant traits for consumers' acceptance, were found similar between all dietary treatments. Also, fillets texture, assessed as firmness and succulence, was not affected by experimental diets. Previous studies also showed that dietary fortification with macroalgae did not alter sensorial traits in trout (Valente et al., 2015) and seabream (Ramalho Ribeiro et al., 2015). However, channel catfish fed a diet supplemented with Se-enriched garlic, flavour traits were significantly altered, although the effect was attributed to the garlic odour and flavour (Schram et al., 2010).

Acceptance of a novel or enriched food product is largely dependent on its positive health and natural image (Dickson-Spillmann, Siegrist \& Keller, 2011). The use of synthetic or non-naturally occurring supplements may undermine consumer perception of enriched food products. Consumers often perceive natural additives as inherently better and healthy, while artificial chemicals in food are associated with higher risk perception (Dickson-Spillmann et al., 2011). A consumer survey performed in Germany, UK and Italy showed a general high acceptance for foods with seaweed ingredients (Buehrlen, Canavari \& Breitschopf, 2005). Brown macroalgae, such as Laminaria digitata, although perceived as a natural product and a rich source of health valuable nutrients (e.g. iodine), may also contain elevated levels of some toxic metals such as arsenic (As) and cadmium (Cd), which may limit their use as food and feed ingredients. In order to protect animals, the consumer and the environment, the European feed legislation (Commission Directive 2002/32/EC and amended by Commission Regulation EU 1275/2013), has set maximum permitted levels for a range of undesirables substances in feed materials and complete compound feeds. Currently, the maximum total arsenic level in feed materials from seaweed and products thereof is $40 \mathrm{mg} \cdot \mathrm{kg}^{-1}$ (or $2 \mathrm{mg} \cdot \mathrm{kg}^{-1}$ of inorganic arsenic) and the maximum total arsenic level in complete fish feeds is $10 \mathrm{mg} \cdot \mathrm{kg}^{-1}$. For cadmium, the current maximum permitted level in both feed materials of vegetable origin and complete fish feed is $1 \mathrm{mg} \cdot \mathrm{kg}^{-1}$. A recent study assessed the potential risks of macroalgae harvested in Norwegian waters when used as feed materials and food for animals and humans (Duinker et al., 2016). Their data showed that several macroalgae species, and particularly brown algae, exceeded the current maximum permitted levels of $\mathrm{Cd}$ and As, clearly limiting their use as ingredients in animals feeds, including fish. However, the high variability on As and Cd levels associated to the geographical origin of the macroalgae and the lower toxicity of organic As forms generally occurring in these marine-derived products are aspects that require further studies to fully elucidate the potential risks associated to their use.

In conclusion, rainbow trout fillets may be successfully tailored to improve its nutritional value conveying an added value for consumers' diets. The supplementation of a traditional trout feed with macroalgae (Laminaria digitata) and selenised yeast significantly enhanced the daily nutritional contribution in iodine and selenium, while vitamin $D_{3}$ and n-3 LCPUFA were also present at high levels. Moreover, the use of natural sources of trace elements, replacing inorganic mineral salts in fish feeds, fits a broader concept of sustainable, chemical-free farming, which is highly appealing to consumers.

\section{Acknowledgements}

The authors would like to acknowledge the excellent contribution and technical work performed by Cátia Silva, Bruno Costa, Vera Rodrigues and Carolina Camacho during the experimental trial, sampling and analytical procedures. This work was undertaken in the framework of project AQUAIMPROV (SAESCTN-PII\&DT/1/2011, NORTE-07-0124FEDER-000038), funded by Programa Operacional Regional do Norte (SAESCTN-PII\&DT/1/2011) (ON.2 - O Novo Norte). Ana Ramalho Ribeiro acknowledges the financial support by FCT/MCTES (Portugal) through grant (SFRH/BD/73452/2010). Selenised yeast (ALKOSEL $®$ R397) was gently provided by Lallemand Animal Nutrition (France). J. D. and P. R. conceived and designed the study. A.R.R., A. G. and J.D. performed the main research work in this study. A.R.R., A.G., N.B., M.L.N., M.T.D., and J.D. contributed to data analysis, results discussion and manuscript writing. All authors revised and approved the final version of the manuscript. The authors declare no conflicts of interest.

\section{References}

Bath, S. C., Steer, C. D., Golding, J., Emmett, P., \& Rayman, M. P. (2013). Effect of inadequate iodine status in UK pregnant women on cognitive outcomes in their children: Results from the Avon Longitudinal Study of Parents and Children (ALSPAC). The Lancet, 382(9889), 331-337. http://dx.doi.org/10.1016/S0140-6736(13)60436-5.

Berr, C., Akbaraly, T., Arnaud, J., Hininger, I., Roussel, A. M., \& Barberger Gateau, P. (2009). Increased selenium intake in elderly high fish consumers may account for health benefits previously ascribed to omega-3 fatty acids. The Journal of Nutrition, Health $\mathcal{E}$ Aging, 13(1), 14-18. http://dx.doi.org/10.1007/s12603-009-0003-3.

Buehrlen, B., Canavari, M., \& Breitschopf, B. (2005). Determinants of consumer preferences towards functional foods with seaweed ingredients. Presented at '97th EAAE seminar on the economics and policy of diet and health'. UK: University of Reading (April 21-22, 2005).

Cashman, K. D., Fitzgerald, A. P., Kiely, M., \& Seamans, K. M. (2011). A systematic review and meta-regression analysis of the vitamin D intake-serum 25-hydroxyvitamin D relationship to inform European recommendations. British Journal of Nutrition, 106(11), 1638-1648. http://dx.doi.org/10.1017/S0007114511005058.

Cohen, Z., Vonshak, A., \& Richmond, A. (1988). Effect of environmental conditions on fatty acid composition of the red alga Porphyridium cruentum: Correlation to growth rate. Journal of Phycology, 24(3), 328-332. http://dx.doi.org/10.1111/j.1529-8817.1988. tb04474.x.

Costa, S., Afonso, C., Bandarra, N. M., Gueifão, S., Castanheira, I., Carvalho, M. L., ... Nunes, M. L. (2013). The emerging farmed fish species meagre (Argyrosomus regius): How culinary treatment affects nutrients and contaminants concentration and associated benefit-risk balance. Food and Chemical Toxicology, 60(0), 277-285. http://dx.doi. org/10.1016/j.fct.2013.07.050.

Cotter, P. A McLean, E \& Craig S. R. (2009). Designing fish for improved human health status. Nutrition and Health, 20(1), 1-9. http://dx.doi.org/10.1177/026010600902000101.

Dickson-Spillmann, M., Siegrist, M., \& Keller, C. (2011). Attitudes toward chemicals are associated with preference for natural food. Food Quality and Preference, 22(1), 149-156. http://dx.doi.org/10.1016/j.foodqual.2010.09.001.

Doucha, J., Lívanský, K., Kotrbáček, V., \& Zachleder, V. (2009). Production of chlorella biomass enriched by selenium and its use in animal nutrition: A review. Applied Microbiology and Biotechnology, 83(6), 1001-1008. http://dx.doi.org/10.1007/ s00253-009-2058-9.

Duinker, A., Roiha, I. S., Amlund, H., Dahl, L., Lock, E. J., Kögel, T., ... Lunestad, B. T. (2016) Potential risks posed by macroalgae for application as feed and food - A Norwegian perspective. Technical report National Institute of Nutrition and Seafood Research (NIFES) (24 pp).

EFSA (2005). Opinion of the scientific panel on additives and products or substances used in animal feed on the request from the commission on the use of iodine in feeding stuffs. EFSA Journal, 168, 1-42.

EFSA (2009). Scientific opinion on the substantiation of health claims related to selenium and protection of DNA, proteins and lipids from oxidative damage (ID 277, 283, 286 $1289,1290,1291,1293,1751$ ), function of the immune system (ID 278), thyroid function (ID 279, 282, 286, 1289, 1290, 1291, 1293), function of the heart and blood vessels (ID 280), prostate function (ID 284), cognitive function (ID 285) and spermatogenesis (ID 396) pursuant to Article 13(1) of Regulation (EC) No. 1924 2006 on request from the European Commission. EFSA Journal, 7(9), 1220. http:// dx.doi.org/10.2903/j.efsa.2009.1220 (24 pp).

EFSA (2014a). Scientific Opinion on health benefits of seafood (fish and shellfish) consumption in relation to health risks associated with exposure to methylmercury. EFSA Journal, 12(7), 3761. http://dx.doi.org/10.2903/j.efsa.2014.3761 (80 pp).

EFSA (2014b). Scientific opinion on dietary reference values for iodine. EFSA Journal, 12(5), 3660. http://dx.doi.org/10.2903/j.efsa.2014.3660 (57 pp). 
EFSA (2014c). Scientific opinion on dietary reference values for selenium. EFSA Journal, 12(10), 3846. http://dx.doi.org/10.2903/j.efsa.2014.3846 (67 pp).

EFSA (2014d). Scientific opinion on dietary reference values for zinc. EFSA Journal, 12(10), 3844. http://dx.doi.org/10.2903/j.efsa.2014.3844 (76 pp).

EFSA (2015a). Draft scientific opinion on dietary reference values for magnesium. EFSA Journal, 13(7), 4186. http://dx.doi.org/10.2903/j.efsa.2015.4186 (63 pp).

EFSA (2015b). Scientific opinion on dietary reference values for vitamin A. EFSA Journal, 13(3), 4028. http://dx.doi.org/10.2903/j.efsa.2015.4028 (84 pp).

EFSA (2015c). Scientific Opinion on the substantiation of a health claim related to vitamin $\mathrm{D}$ and contribution to the normal function of the immune system pursuant to Article 14 of Regulation (EC) No. 1924/2006. EFSA Journal, 13(5), 4096. http://dx.doi.org/10. 2903/j.efsa.2015.4096 (7 pp).

FAO (2015). Food outlook: Biannual report on global food markets - May 2015. Rome: FAO Trade and Markets Division (136 pp).

FAO/WHO (2011). Report of the joint FAO/WHO expert consultation on the risks and benefits of fish consumption. Rome, Geneva: Food and Agriculture Organization of the United Nations; World Health Organization (50 pp).

Folch, J., Lees, M., \& Stanley, G. H. S. (1957). A simple method for the isolation and purification of total lipids from animal tissues. Journal of Biological Chemistry, 226(1), 497-509.

Hunt, A. O., Berkoz, M., Ozkan, F., Yalin, S., Ercen, Z., Erdogan, E., \& Gunduz, S. G. (2011) Effects of organic selenium on growth, muscle composition, and antioxidant system in rainbow trout. Israeli Journal of Aquaculture - Bamidgeh, 63(562), 1-10 (IIC: 63. 2011.562, 10 pp).

Hurrell, R. (1997). Bioavailability of iodine. European Journal of Clinical Nutrition, 51(1), S9.

IOM (2001). Dietary reference intakes for vitamin A, vitamin $K$, arsenic, boron, chromium, copper, iodine, iron, manganese, molybdenum, nickel, silicon, vanadium, and zinc. Washington, DC, USA: The National Academies Press.

IOM (2005). Dietary reference intakes for water, potassium, sodium, chloride, and sulfate. Washington, DC, USA: The National Academies Press.

IOM (2011). Dietary reference intakes for calcium and vitamin D. Washington, DC: The National Academies Press.

ISSFAL (2004). Recommendations for intake of polyunsaturated fatty acids in healthy adults. Brighton, UK: International Society for the Study of Fatty Acids and Lipids (22 pp).

Julshamn, K., Dahl, L., \& Eckhoff, K. (2001). Determination of iodine in seafood by inductively coupled plasma/mass spectrometry. Journal of AOAC International, 84(6) 1976-1983.

Julshamn, K., Maage, A., Waagbø, R., \& Lundebye, A. K. (2006). A preliminary study on tailoring of fillet iodine concentrations in adult Atlantic salmon (Salmo salar L.) through dietary supplementation. Aquaculture Nutrition, 12(1), 45-51. http://dx.doi.org/10. 1111/j.1365-2095.2006.00380.x.

Kennedy, S. R., Bickerdike, R., Berge, R. K., Dick, J. R., \& Tocher, D. R. (2007). Influence of conjugated linoleic acid (CLA) or tetradecylthioacetic acid (TTA) on growth, lipid composition, fatty acid metabolism and lipid gene expression of rainbow trout ( $\mathrm{On}$ corhynchus mykiss L.). Aquaculture, 272(1-4), 489-501. http://dx.doi.org/10.1016/j. aquaculture.2007.06.033.

Kouba, A., Velî̌̌ek, J., Stará, A., Masojídek, J., \& Kozák, P. (2014). Supplementation with sodium selenite and selenium-enriched microalgae biomass show varying effects on blood enzymes activities, antioxidant response, and accumulation in common barbel (Barbus barbus). BioMed Research International, 2014, 8. http://dx.doi.org/10.1155 2014/408270.

Küçükbay, F. Z., Yazlak, H., Karaca, I., Sahin, N., Tuzcu, M., Cakmak, M. N., \& Sahin, K. (2009). The effects of dietary organic or inorganic selenium in rainbow trout (Oncorhynchus mykiss) under crowding conditions. Aquaculture Nutrition, 15(6), 569-576. http://dx.doi.org/10.1111/j.1365-2095.2008.00624.x.

Lepage, G., \& Roy, C. C. (1986). Direct transesterification of all classes of lipids in a onestep reaction. Journal of Lipid Research, 27(1), 114-120.

Lorentzen, M., Maage, A., \& Julshamn, K. (1994). Effects of dietary selenite or selenomethionine on tissue selenium levels of Atlantic salmon (Salmo salar). Aquaculture, 121(4), 359-367. http://dx.doi.org/10.1016/0044-8486(94)90270-4.

Maage, A., Julshamn, K., \& Ulgenes, Y. (1991). A comparison of tissue levels of four essential trace elements in wild and farmed Atlantic salmon (Salmo salar). Fiskeridirektoratets Skrifter Serie Ernoering, 4, 111-116.

Meilgaard, M., Civille, G. V., \& Carr, B. T. (1999). Sensory evaluation techniques (3rd ed.). Florida, USA: CRC Press LLC.

Moreda-Piñeiro, J., Moreda-Piñeiro, A., \& Bermejo-Barrera, P. (2015). In-vivo and in-vitro testing for selenium and selenium compounds bioavailability assessment in foodstuff. Critical Reviews in Food Science and Nutrition. http://dx.doi.org/10.1080/10408398. 2014.934437 (00-00).
Navarro-Alarcon, M., \& Cabrera-Vique, C. (2008). Selenium in food and the human body: A review. Science of the Total Environment, 400(1-3), 115-141. http://dx.doi.org/10. 1016/j.scitotenv.2008.06.024

Pacitti, D., Lawan, M. M., Sweetman, J., Martin, S. A. M., Feldmann, J., \& Secombes, C. J. (2015). Selenium supplementation in fish: A combined chemical and biomolecular study to understand Sel-Plex assimilation and impact on selenoproteome expression in rainbow trout (Oncorhynchus mykiss). PLoS ONE, 10(5), e0127041. http://dx.doi. org/10.1371/journal.pone.012704.

Raatz, S. K., Silverstein, J. T., Jahns, L., \& Picklo, M. J. (2013). Issues of fish consumption for cardiovascular disease risk reduction. Nutrients, 5(4), 1081-1097. http://dx.doi.org/ 10.3390/nu5041081.

Ramalho Ribeiro, A., Gonçalves, A., Colen, R., Nunes, M. L., Dinis, M. T., \& Dias, J. (2015). Dietary macroalgae is a natural and effective tool to fortify gilthead seabream fillets with iodine: Effects on growth, sensory quality and nutritional value. Aquaculture, 437(0), 51-59. http://dx.doi.org/10.1016/j.aquaculture.2014.11.028.

Ramos, A., Bandarra, N. M., Rema, P., Vaz-Pires, P., Nunes, M. L., Andrade, A. M., ... Valente, L. M. P. (2008). Time course deposition of conjugated linoleic acid in market size rainbow trout (Oncorhynchus mykiss) muscle. Aquaculture, 274(2-4), 366-374. http://dx. doi.org/10.1016/j.aquaculture.2007.11.040.

Rider, S. A., Davies, S. J., Jha, A. N., Fisher, A. A., Knight, J., \& Sweetman, J. W. (2009). Supranutritional dietary intake of selenite and selenium yeast in normal and stressed rainbow trout (Oncorhynchus mykiss): Implications on selenium status and health responses. Aquaculture, 295(3-4), 282-291. http://dx.doi.org/10.1016/j.aquaculture. 2009.07.003.

Rodríguez, P. H., \& Rojas, M. S. (2014). Efecto de dietas enriquecidas con vitamina e y selenio orgánico en el comportamiento productivo y calidad funcional del filete de trucha arco iris (Oncorhynchus mykiss). Revista de Investigaciones Veterinarias del Perú, 25, 213-225.

Rosa, R., Andrade, A. M., Bandarra, N. M., \& Nunes, M. L. (2010). Physiological and biochemical effects of conjugated linoleic acid and its use in aquaculture. Reviews in Aquaculture, 2(2), 59-72. http://dx.doi.org/10.1111/j.1753-5131.2010.01021.x.

Schmid, A., \& Walther, B. (2013). Natural vitamin D content in animal products. Advances in Nutrition, 4(4), 453-462. http://dx.doi.org/10.3945/an.113.003780.

Schmid, S., Ranz, D., He, M. L., Bukard, S., Lukowicz, M. V., Reiter, R., ... Rambeck, W. A. (2003). Marine algae as natural source of iodine in the feeding of freshwater fish A new possibility to improve iodine supply of man. Revue de Médecine Vétérinaire, 154(10), 645-648.

Schram, E., Schelvis-Smit, R. A. A. M., Van Der Heul, J. W., \& Luten, J. B. (2010). Enrichment of the African catfish Clarias gariepinus (Burchell) with functional selenium originating from garlic: Effect of enrichment period and depuration on total selenium level and sensory properties. Aquaculture Research, 41(6), 793-803. http://dx.doi.org/10. 1111/j.1365-2109.2009.02356.x.

Shahidi, F., \& Ambigaipalan, P. (2015). Novel functional food ingredients from marine sources. Current Opinion in Food Science, 2(0), 123-129. http://dx.doi.org/10.1016/j. cofs.2014.12.009.

Stoffaneller, R., \& Morse, N. (2015). A review of dietary selenium intake and selenium status in Europe and the Middle East. Nutrients, 7(3), 1494.

Ulbricht, T. L. V., \& Southgate, D. A. T. (1991). Coronary heart disease: Seven dietary factors. The Lancet, 338(8773), 985-992. http://dx.doi.org/10.1016/01406736(91)91846-M

Valente, L. M. P., Rema, P., Ferraro, V., Pintado, M., Sousa-Pinto, I., Cunha, L. M., ... Araújo, M. (2015). Iodine enrichment of rainbow trout flesh by dietary supplementation with the red seaweed Gracilaria vermiculophylla. Aquaculture, 446, 132-139. http:// dx.doi.org/10.1016/j.aquaculture.2015.05.004.

Van Paemel, M., Dierick, N., Janssens, G., Fievez, V., \& De Smet, S. (2010). Selected trace and ultratrace elements: Biological role, content in feed and requirements in animal nutrition - Elements for risk assessment. EFSA Supporting Publication 2010, 7(7), EN68. http://dx.doi.org/10.2903/sp.efsa.2010.EN-68 (1132 pp).

Verbeke, W. (2005). Consumer acceptance of functional foods: Socio-demographic, cognitive and attitudinal determinants. Food Quality and Preference, 16(1), 45-57. http://dx.doi.org/10.1016/j.foodqual.2004.01.001.

Weihrauch, J., Posati, L., Anderson, B., \& Exler, J. (1977). Lipid conversion factors for calculating fatty acid contents of foods. Journal of the American Oil Chemists' Society, 54(1), 36-40. http://dx.doi.org/10.1007/bf02671370.

WHO (2007). Assessment of iodine deficiency disorders and monitoring their elimination: A guide for programme managers (3rd ed.). Geneva, Switzerland: World Health Organization (98 pp). 